\author{
Olha Gladun Ольга Гцадун \\ Candidate in Art Studies, Docent, director of the Regional Art \\ Museum, Communal Institution of the Cherkasy Regional \\ Council \\ Аоцент, кандиАат мистецтвознавства, Комунальна устано- \\ ва «Обласний художній музей» Черкаської обласної ради, \\ Аиректор музею
}

тем. / tel: +380506992211, +380631215567 e-mail: gladunol@ukr.net orcid.org/0000-0001-9464-2730

\title{
Range of Issues of Contemporary Visual Culture: Visual, Information, Media
}

\author{
Проблемне поме сучасної візуальної культури: \\ Візуальне, інформаційне, медійне
}

\begin{abstract}
The article actualizes the problem of contemporary visual and information culture, of visual language, and of discourse as a methodological approach, which is applied for the analysis of modern communicative practices of social reality. Concepts of "visual", "information", and "media" are defined. The interaction and differences between the notions of information and media cultures, based on semiotic and hermeneutic methods of researching the discursive field of visual culture, are analyzed.

Keywords: visuality, visual information culture, media culture, information and communication processes.
\end{abstract}

Problem statement. Researching the issue of visuality of the recent years marks important changes in culture. Processes of meaning making constitute the subject field of these studies. This determines a research interest to the transformations in the visuality subject field, related to the changes in the format of culture (the one that is often labeled "information culture"). In fact, culture overall is information culture in a sense that it is rooted in universal processes of receiving and transmitting information.

Contemporary individual lives in the visual-information world, with information being the chief value of the latter. Archaic expression "want to know - then read" had long been restated as "want to know-than watch". Information flows became so intense and their speed so fast that sign systems, based on the modernism method, do not handle organization and managing of contemporary visual information.

In the $21^{\text {st }}$ century concept and ideas, not based on logical calculations and guidelines, become more and more influential within the information space. Contemporary methodology of creating and presenting harmonious visual information is still in the making. Signs, sign systems, visual messages (such as posters, postcards, labels, covers, packaging), produced during the previous, modernist period, despite their clarity, logic, aesthetical presentation of the material are now morally outdated. They are unable to accomplish the design tasks, set by contemporary media. All becomes a thing of the past very quickly: be it information, information flows or their transmitters.

Understanding culture as a development of science and art, as a field of social relations, aimed on preserving and harmonization of human being, considering ecology issues, that is, information space glutted with aggressive, filthy, low quality visual information (aggressive adverts as an object for manipulations, fake stories, various visual noise that expand catastrophically), empowers us to actualize the issues of visual-information culture.

Analysis of recent research works and publications. Due to changes in communicational field of culture, "vision" becomes the central theoretical problem of the $20^{\text {th }}$ century (researched by Rudolf Arnheim [1], Vadim Rozin [22]). Making reality a central problem of a study creates a discursive field of visuality that is based on semiotic and hermeneutic methods.

Issues of semiotics and semiosphere of visual culture were presented in the classical works by: Ernst Cassirer [7], Susanne Langer [11], Charles Sanders Peirce [15], Yevgeniy Basin [2], Mikhail Lotman [12], as well as in the publications of Ukrainian authors: V. Tarasenko [25], V. Feschenko and $\mathrm{O}$. Koval [28], who researched image, sign, symbol, nature of code and coding in art. The visual language range of problems within the system of contemporary visual communications (communicative approach) has been studied by S. KhanMagomedov [29], K. Konsratieva [9], P. Rodkin [21] etc.

Innovations of media culture and media communications have been researched by V. Savchuk [23], D. Rashkov [19] and others. Media turn actualizes an objective to differentiate information and media culture within the context of visual culture.

Objectives of the research: to investigate structural and semantic elements of discursive field of visual culture, 
to define concepts of the "visual", the "information", the "media" that would be productive for formulating an idea of contemporary visual-information culture.

Presentation of the main research material. In the $20^{\text {th }}$ century visual culture shaped up in the new type of textuality, therefore it should still incorporate some traits of the replaced object: being a text, but based on other visual carriers. That means contemporary visual language, its sense characteristics and decoding methods of visual artefacts. The concept of "visual language" becomes yet more topical during studying the interaction of different cultural formats, cultural ontological images. Discursive dimensions of the visual deepen and expand during contemporary communicational changes.

These days the concept of discourse is extremely broad and vague, as it is used "to denote both texts and all the forms of communication, as well as sign-symbolic forms of presentations" [14, p. 194].

Such institutionalized type of discourse as a visual one is marked with the existence of other types of discourses and lack of clear distinctions between them. During the $20^{\text {th }}$ century visual discourse becomes total, incorporating into its orbit the new formats of culture and cultural phenomena, that are not typical for the classical mainstream line of "order of discourse", that retranslate senses through the aggregate of different textualities. It exists in the process of permanent change of human identity, of the models of memory and ways of aesthetical perception of the world. That is the reason to include a wide range of phenomena into the visual discourse of the present day, objectivated in different textualities and represented in culture.

Thus, media become a "demiurge" of the new format of reality. Still, despite the media discourse being a "kernel zone" for majority of other discourses (political, sport, rock, auto), the visual discourse includes the space of the whole culture in its diachronic and synchronic dimensions. Another question is the difference between the concepts of information and media cultures.

The issue of defining and researching information culture lies in the polysemantic nature of the term, in its multidisciplinary and multi-faceted nature. For instance, in the theories by Manuel Castells, Alvin Toffler [26] and Alain Touraine [27] "information society acts as a certain form of post-industrial social-economic development and generally is viewed as a model of development of social relations and connections, which is being formed based on achievements of 'e-revolution', as well as on the rapid development of computer hardware, information and communication software" [17, p. 9].

In our opinion, it would be productive to address Manuel Castells' concept with his ideas of information society, aimed on accumulating knowledge and production of more complicated forms of processing information that becomes the basis for creating the new "galaxy of communications" [8, p. 316].

The only origin for senses, according to Castells, is identity. Castells' concept actualizes issues of influence on human mind not by the very information, but by the senses, enclosed in it. He "tears off" information from its straight connection with the technical means of its production and transformation, binding it directly with the human work, and putting its functioning into direct dependence from the social subjects' activity. The scholar formulates a definition of informational and global economies, in which he reveals the meaning of contemporary form of social communications, “... informational because productivity and competitiveness of factors and agents in this economies (be it a firm, a region or a nation) depend primarily on the ability to generate, process and use the information based in knowledge effectively" $[8$, p. 14].

Accordingly, Castells defined the core of contemporary informational and technological revolution, "What characterizes the current technological revolution is not the central personage of knowledge and information, but rather the application of this knowledge and information to knowledge generation and information/communication processing devices, in a cumulative feedback loop between innovation and the uses of innovation" [8, p. 51].

New information technologies are not simply instruments that should be used, but the processes that ought to be developed. Interrelation between complicated processes of the early millennium created "a new economy, the informational/global economy; and a new culture, the culture of real virtuality. The logic embedded in this economy and society and culture underlines all institutions in an interdependent world" [8, p. 492], thus "information technology revolution provoked emergence of informationalism as a material basis of the new society" [8, p. 492].

For the adequate understanding of social relations in the era of computer engineering and new means of connection, it is necessary to study changes in the structure of communication experience and in the principles of coding and symbolization.

David Robertson, American scholar, proves that "principle of coding information directly influences the level and quality of knowledge, starting with the first communicational revolution, linked to language development, and ending with the latest one-electronic, network revolution; this principle of information coding defines features of culture, dominant during certain period of time" [8, p. 378].

The transfer, being made these days, is from the "Guttenberg galaxy" to the "McLuhan galaxy": printed word is being substituted with the expansion of visual images. Media (from the Greek core or middleman): as in the Mediterranean Sea, or medium-middleman between the Creator and an artwork. Contemporary meaning of "media" is the means, providing communication to people or groups of people. Nowadays media are all the means of mass communications, as well as means of mass personal communication and so called network multimedia means. In the traditional understanding, media culture becomes aggregate of all kinds of audiovisual art. However, contemporary individual gradually enters the media reality as its active participant, affirming not only the means of information 
transfer, but also the new type of information society, comprising of various information media (photography, cinema, radio, telephone, television, as well as digital technologies of recording information, and computer), through the explanation of concept characteristics of information culture and information society.

How does the interaction between information and media cultures look like? Media culture is a logical extension of the information culture, a new locus of its informational specificity, its new quality state. It requires new media competence to master new screen mediums: computer, tablet, telephone, etc.

Network culture develops, based on contacts between people on different levels, on their non-linear rhizome-like interaction. Certain style structure is being built within it, forming a special field of values and senses. This structure embeds into people's worldview and defines the core of culture. Informational communication networks become channels of cultural senses' migration and, obviously, affect the process of the subject's self-identification.

Communication practices of the social reality act as a senses-forming systems and form of retranslating these senses. Virtual reality sets a defining optical and acoustic impact on the transformation of spiritual and corporal identification of an individual.

Designer and artist of the modernism paradigm relied on the adjusted laws of semiotics and semiurgy. The laconicism of the modernists' visual image was the form of clear retranslation of information, probably, even the form of opposition to the low-quality visual information. The laws of classical composition defined effective transmission of the informational sense, "took care" about the harmonization of the visual information' impact. They were not the information, visual messages, but the works of art, capturing the viewer with the accuracy of choices, originality of metaphors and novelty of images even now. The "minimaxi" principle, genetically rooted in the avant-garde poster, in the 1960s received a new status of a quality design. With the information becoming more complex, from the one hand, and with the expressive cliché becoming more and more empty, with the visual stereotypes rapidly aging, a certain plastic crisis occurs in the semiurgy of the 1980s.

During the late 1980s, pluralism of the Ukrainian New Wave movement (historically resulting from the reaction on a professional crisis) causes emergence of new, complex, "pictorial" graphic objects. The laconicism of the modernism aesthetics was disturbed not only with the polysemanticism of the new signs, but also with the unprofessional, chaotic semiurgy. Besides that, for some time the anti-aesthetical demands of a consumer (being always right) turned so call graphic design production into conformist, unprofessional creations. However, graphic design development of the 1990s piles this random semiurgy up too high, proving the need for a new professional standards for a designer.

In contrast to the strict commercial technologies, a new ecological direction emerges in the graphic design. It make emphasis on the spiritual, cultural, intellectual senses of signs that "contributed to preventing functional-consumer attitude to the world, separation the sense of the message from its form and manipulations with it" [30, p. 77].

If a pointed sign-substitute is characteristic of modernism, than for postmodernism sign is a part of collective corporate identity. Thus, contemporary sign no longer identifies a trademark style, but reveals identity. From the formal point of view, numerous copyright signs prove to be the expressions of identity; from the meaning point of view, they are occasions for actualization of the national identity issues, working on specific national language features. Understanding that visual language is a language of the global information space, it is evident that this language should be perfectly simply, convenient and clear. In that way the sign system of visual stereotypes is being developed, adjusted as much as possible.

For the creation of signs and sign systems the semiotic approach is used. However, strict semiotic matrixes that rely on the studies of discrete, formalized texts and languages are not quite productive. They do not work with contemporary visual continuum. Optical density of the visual space, constant flow of visual information complicate distinguishing separate visual messages. They merge and form random texts, happen to be perceived in different contexts, become snatches of old contexts.

Alas, today the products of graphic design (namely, the design of visual communications) are numerous various project practices in visualization, developing and creation of signs, sign systems, navigation systems, visual messages, visual texts that are being transmitted through different channels of communication and exist in the unstructured, visually polluted general and local information environment.

We live through the situation we have found ourselves in for the first time: in the previous eras information forced culture to create channels of communications that would suit its parameters; nowadays the message itself shows ability to choose, differentiate and format information.

In contemporary culture the only legitimate are the things, "adapted to the mass media mode and transmittable" [10, p. 191]. Such information does not always convey any senses. More often, it "manipulates sense and stimulates its presence” [10, p. 191].

Information fundamentally could be coded within any outer artifact, as what matters is not a sign but the embedded meaning. "In this sense information network is a network of meanings, it is a material embodiment that proves the transition of humankind to some new level of understanding and self-understanding" [5, p. 73]. The subject of culture has to make efforts to build senses of phenomena. Concentration on the very process of producing hybrid meanings is a trait of our reality. Therefore, searching for methodology that would be adequate to the time is a pressing issue of the present day.

If intellectualization of perceiving art in the early $20^{\text {th }}$ century sets grounds for spreading the method, capable not only to explain contemporary cultural artifacts, but to create a powerful projection into the past of cultural senses' formation, therefore the possibility of creating such projection 
into the future (with a condition of flexibility and universality of contemporary methodological matrix) would be topical. Polymethodology does not mean absorbing all other theories by some single one: on the contrary, it assumes their simultaneous co-existence. Nevertheless, in a contemporary cultural field we observe not only polymericity and hybridization of the depicted, but also of the methods of study.

In contemporary media communication, sensory synesthesia (integrity of sensory complex) is rather limited or transformed. Type of such transformation is studied from the position of the subject of perception (Homo-somaticus, Homosentiens etc.). The main point is that the aim of the subject of that culture is not embellishment of the reality, but escape (salvation) from it. Spontaneous feelings weaken, therefore media communication contexts appeal not to the basis of our practices, but rather to the experience of the fragments of the body. When body is not involved in emotions, the latter are surrogate. Body experience forces an individual to face true emotions, thus arises the need of filling in the senses of corporality. That happens through the contextual "intergrowth" of the actual and virtual realities. "Fragmentization becomes a hybrid type of rationality" [10, p. 174] and form labyrinths of senses, multiplicity of interpretations and invariance of the contexts in a journey through texts. It is often a result of the broken balance between different formats of reality and adaptational choice of a person in favor of the virtual format of reality. Visual humanization today is the responsibility of the artificial worlds' creators for transmission of senses, as the "Media is a place of setting senses, i. e. not communication, but semiurgy. The main point of media-design is help in receiving access to the unrevealed potential that grants the possibility of development. Its visual artifacts are not sources of information, but spiritual resonators that have ontological meaning, giving life to things and phenomena, rooting them in culture. They are built in a way that forces the viewer to think and make decisions" [30, p. 77].

\section{References}

1. Arnheym R. Iskusstvo i vizualnoe vospriyatie. Moskva: Progress, 1974. $386 \mathrm{~s}$.

2. Basin E. Ya. Iskusstvo i kommunikatsiya (ocherki iz istorii filosofsko-esteticheskoy myisli). Moskva: Moskovskiy obschestvennyiy nauchnyiy fond; Izdatelskiy tsentr nauchnyih i uchebnyih programm, 1999. $240 \mathrm{~s}$.

3. Vy`selko I.V. Transformaciya kul `turny`kh smy`sliv u konteksti audiovizual 'noyi komunikaciyi: dy`s. ... kand. filos. nauk: 26.00.01 / Ky'yiv. nacz. un-t im. Tarasa Shevchenka. Ky'yiv, 2016. 218 s.

4. Vy`sheslavs 'ky`j G., Sy` dor-Gibely`nda O. Terminologiya suchasnogo my`stecztva. Ky`yiv, Pary`zh: Terra Incognita, 2010.416 s.

5. Havrylenko I. M. Merezheve suspil'stvo yak ponyattya, obraz ta istorychna perspektyva. Sotsiolohiya: teoriya, metody, marketynh. Kyyiv, 2012.\# 1. S. 62-81.

6. Zubavina I. B. Chas i prostir u kinematografi. Ky`yiv: Shhek, 2008. $447 \mathrm{~s}$.

7. Kassirer E. Filosofiya simvolicheskih form: V 3 t. Moskva, SanktPeterburg: Universitetskaya kniga, 2001-2002. Tom 1. Yazyik. 272 s.
Conclusions. Contemporary visual discourse includes a wide range of phenomena that is objectivated in different textualities and represented in culture.

Interaction of visual, information and media cultures show relations of intersection. The concept of "visual-information culture" in a contemporary discourse does not have a single meaning and is related to the "culture" concept as a part to a whole, as a sub-system to a system. Correspondingly, this sub-system is brought into being from the combination of two other systems - "visuality" and "informativeness".

Media culture is a logical sequel of information culture on the new stage of its existence, a new aspect of its information specificity, its new quality state. It requires media competence in mastering the functions of its predecessors. Emergence of media culture produced new research discourse, became a result and simultaneously an aim of the ontologically-oriented studies, which focus on the concept of reality and on the interrelation of its various formats. As for the visual-information culture, its range of issues to be studied are, primarily, functioning of the sign systems in situation of contemporary culture, including the media culture, changes in the visual codes and emergence of the new forms of visual communication.

The format of contemporary visual culture that comprises informational culture with its iconic and semiology backgrounds and media culture, based on the poststructuralist methodology, may be defined as a visual-information culture.

Visual culture in all times maintain the specificity of information culture. In the era of media, it presents the highly complex model of information space that is not limited to the visual. Yet, in the very theory of information society ripens the idea of changing the role of information in culture, therefore it would be appropriate to define culture, directly related to visual images, as the visual-information culture.

\section{Мітература}

1. Арнхейм Р. Искусство и визуальное восприятие. Москва: Прогресс, 1974. $386 \mathrm{c}$.

2. Басин Е.Я. Искусство и коммуникация (очерки из истории фимософско-эстетической мысли). Москва: Московский общественный научный фонА; ООО «ИзАательский центр научных и учебных программ», $1999.240 \mathrm{c}$.

3. Виселко I.В. Трансформація культурних смислів у контексті ауАіовізуальної комунікації: Аис. ... канд. філос. наук: 26.00.01 / Київ. нац. ун-т ім. Тараса Шевченка. Київ, 2016. 218 с.

4. Вишеславський Г., Сидор-Гібелинда О. Термінологія сучасного мистецтва. Київ, Париж: Terra Incognita, 2010. 416 с.

5. Гавриленко I.M. Мережеве суспільство як поняття, образ та історична перспектива. // Соціологія: теорія, методи, маркетинг. 2012. № 1. С. 62-81.

6. Зубавіна І.Б. Час і простір у кінематографі. Київ: Щек, 2008. $447 \mathrm{c.}$

7. Кассирер Э. Философия символических форм: В 3 т. Москва, Санкт-Петербург: Университетская книга, 2001-2002. Т. 1. Язык. 
Tom 2. Mifologicheskoe myishlenie. 280 s. Tom 3. Fenomenologiya poznaniya. $398 \mathrm{~s}$.

8. Kastels M. Informatsionnaya epoha: ekonomika, obschestvo i kultura / per. s angl. pod nauch. red. O. I. Shkaratana. Moskva: GU VShE, 2000. $608 \mathrm{~s}$.

9. Kondrateva K.A. Dizayn i ekologiya kulturyi. Moskva: MGHPU im. Stroganova, 2000. $105 \mathrm{~s}$.

10. Kostina A.V. Massovaya kultura kak fenomen postindustrialnogo obschestva. Moskva: Editorial URSS, 2005. $352 \mathrm{~s}$.

11. Langer $S$. Filosofiya $v$ novom klyuche: Issledovanie simvoliki razuma, rituala i iskusstva / per. s angl. S. P. Evtushenko. Moskva: Respublika, 2000.287 s.

12. Lotman Yu.M. Struktura hudozhestvennogo teksta. SanktPeterburg: «Iskusstvo — SPB», 1998. S. 14-285.

13. Mankovskaya N.B. Globalizatsiya à la russe: hudozhestvenno-esteticheskiy rakurs. Estetika: Vchera. Segodnya. Vsegda. Moskva: IF RAN, 2008. Vyip. 3. S. 24-57.

14. Nagorna L.P. Regional'na identy'chnist': ukrayins 'ky'j kontekst. Ky'yiv: IPiEND imeni I. F. Kurasa NAN Ukrayiny', 2008. 405 s. 15. Pirs Ch. S. Izbrannyie filosofskie proizvedeniya. Moskva: Logos, 2000. $412 \mathrm{~s}$.

16. Porus V.N. Ratsionalnost. Nauka. Kultura: sbornik. Moskva: Universitet Rossiyskoy Akademii obrazovaniya. Kafedra filosofii, 2002.352 s.

17. Prudny 'kova O.V. Informacijna kul 'tura: konceptual 'ni zasady' ta svitoglyadny ’ j sens: monografiya. Kharkiv: Pravo, 2015.352 s.

18. Puchkov A.A. Arhitekturovedenie i kulturologiya: izbr. st. Kiev: Izd. dom A.S.S., 2005. 684 s.

19. Rashkoff D. Mediavirus. Moskva: Ultra. Kultura, 2003. 392 s.

20. Rogotchenko O.O. Socialisty`chny`j realizm i totalitary`zm / In-t probl. suchas. my`stecz. Akad. my`stecz. Ukrayiny`. Ky`yiv: Feniks, 2007.604 s.

21. Rodkin P. Futurizm i sovremennoe vizualnoe iskusstvo. Moskva: Sovpadenie, 2006. $253 \mathrm{~s}$.

22. Rozin V.M. Vizualnaya kultura i vospriyatie: kak chelovek vidit i vosprinimaet mir. Moskva: Editorial URSS, 2004. $224 \mathrm{~s}$.

23. Savchuk V.V. Mediafilosofiya. Pristup realnosti. Sankt-Peterburg: Izdatelstvo RHGA, 2014. $350 \mathrm{~s}$.

24. Sy'dorenko V.D. Vizual'ne my`stecztvo vid avangardny'kh zrushen ' do novitnikh spryamuvan`: rozvy' tok vizual. my`stecztva Ukrayiny` XX-XXI stolittya / Akad. my`stecztv Ukrayiny', In-t probl. suchas. my`stecztva. Ky`yiv: VKh [studio], 2008. $188 \mathrm{~s}$.

25. Tarasenko V. Fraktalnaya semiotika. Slepyie pyatna, peripetii i uznavaniya. Moskva: Librokom, 2009. $232 \mathrm{~s}$.

26. Toffler E. Tretya volna. Moskva: Izdatelstvo AST, $2010.784 \mathrm{~s}$.

27. Turen A. Vozvraschenie cheloveka deystvuyuschego. Ocherk sotsiologii. Moskva: Nauchnyiy mir, 1998. $204 \mathrm{~s}$.

28. Feschenko V.V., Koval O.V. Sotvorenie znaka: Ocherki o lingvoestetike i semiotike iskusstva: nauchnaya monografiya. Moskva: Yazyiki slavyanskoy kulturyi, 2014. 640 s.

29. Han-Magomedov S.O. Suprematizm i arhitektura (problemyi formoobrazovaniya). Moskva: Arhitektura-S, 2007.520 s.

30. Pushonkova O.A. The persrective of the visual language in the space of contemporary culture. Visny'k Cherkas 'kogo universy`tetu. Seriya «Filosofiya». Cherkasy`: ChNU, 2015. Vy` p. \#31 (364). S. 73-80.
272 с. Том 2. Мифологическое мышиение. 280 с. Том 3. Феноменология познания. 398 с.

8. Кастельс М. Информационная епоха: экономика, общество и культура / пер. с англ. поА науч. реА. О.И. Шкаратана. Москва: ГУ ВШЭ, 2000. 608 с.

9. Кондратьева К.А. Аизайн и экология культуры. Москва: МГХПУ им. Строганова, 2000. 105 с.

10. Костина А.В. Массовая культура как феномен постиндустриального общества. Москва: ЕАиториал УРСС, 2005. 352 с.

11. Аангер С. Философия в новом ключе: Исследование символики разума, ритуала и искусства / пер. с англ. С.П. Евтушенко. Москва: Респубиика, 2000. 287 с.

12. Аотман Ю.М. Структура художественного текста. Санкт-Петербург: «Искусство - СПБ», 1998. С. 14-285.

13. Маньковская Н.Б. ГАобализация à la russe: художественно-эстетический ракурс. // Эстетика: Вчера. Сегодня. ВсегАа. Москва: ИФ РАН, 2008. Вып. 3. С. 24-57.

14. Нагорна А. П. Регіональна ідентичність: український контекст. Київ: ІПіЕНА імені І. Ф. Кураса НАН України, 2008. 405 с.

15. Пирс Ч. С. Избранные фимософские произведения. Москва: Аогос, 2000.412 с.

16. Порус В. Н. Рациональность. Наука. Культура: сборник. Москва: Университет Российской Академии образования. Кафедра фимософии, 2002. 352 с.

17. Прудникова О.В. Інформаційна культура: концептуальні засаАи та світоглядний сенс: Монографія. Харків: Право, 2015. 352 с.

18. Пучков А.А. Архитектуроведение и культурология: Избр. ст. Киев: А.С.С., 2005.684 с.

19. Рашкофф А. Медиавирус. Москва: УАьтра. Культура, 2003. 392 с. 20. Роготченко О.О. Соціалістичний реалізм і тоталітаризм // Ін-т пробл. сучас. мистец. АкаА. мистец. України. Київ: Фенікс, $2007.604 \mathrm{c}$.

21. Родькин П. Футуризм и современное визуальное искусство. Москва: Совпадение, 2006. 253 с.

22. Розин В.М. Визуальная культура и восприятие: как человек виАит и воспринимает мир. Москва: ЭАиториал УРСС, 2004. 224 с.

23. Савчук В.В. Медиафилософия. Приступ реальности. СанктПетербург: ИзАательство РХГА, 2014. 350 с.

24. Сидоренко В.А. Візуальне мистецтво віА авангардних зрушень Ао новітніх спрямувань: розвиток візуал. мистецтва України XXXXI століття / АкаА. мистецтв України, Ін-т пробл. сучас. мистецтва. Київ: ВХ [стуАіо], 2008. 188 с.

25. Тарасенко В. Фрактальная семиотика. Слепые пятна, перипетии и узнавания. Москва: Аиброком, 2009. 232 с.

26. Тоффлер Э. Третья волна. Москва: АСТ, 2010.784 с.

27. Турен А. Возвращение чемовека действующего. Очерк социомогии. Москва: Научный мир, 1998. 204 с.

28. Фещенко В.В., Коваль О.В. Сотворение знака: Очерки о мингвоэстетике и семиотике искусства: научная монография. Москва: Языки славянской культуры, 2014. 640 с.

29. Хан-Магомедов С. О. Супрематизм и архитектура (проблемы формообразования). Москва: Архитектура-С, 2007. 520 с.

30. Pushonkova O.A. The perspective of the visual language in the space of contemporary culture // Вісник Черкаського університету. Серія «Фімософія». 2015. Вип. № 31 (364). С. 73-80. 
ГАадун О.А.

Проблемне поле сучасної візуальної кумьтури: Візуальне, інформаційне, медійне

Анотація. Актуалізовано питання сучасної візуально-інформаційної культури, візуальної мови, а також Аискурсу як методомогічного піАходу, що застосовується Аля аналізу сучасних комунікативних практик соціальної реальності. Проаналізовано взаємодію та відмінності між поняттями інформаційної та медійної культур, грунтуючись на семіотичних та герменевтичних методах досліАження дискурсивного помя візуальної культури. Робиться спроба Аати визначення понять «візуальне», «інформаційне», «медійне» в контексті завдань статті.

Ключові слова: візуальність, візуально-інформаційна культура, медійна культура, інформаційно-комунікативні процеси.

\section{ГАалун О.А.}

Проблемное поле современной визуальной кумьтуры: визуахьное, информационное, меАийное

Аннотация. Актуализирован вопрос современной визуально-информационной культуры, визуального языка, а также Аискурса как методологического подхода, применяемого Аля анализа современных коммуникативных практик социальной реальности. Проанализировано взаимодействие и различия межАу понятиями информационная и медийная культура, основываясь на семиотических и герменевтических методах исследования дискурсивного поля визуальной культуры. Аелается попытка Аать определение понятиям «визуальное», «информационное», «медийное» в контексте задач статьи.

Ключевые слова: визуальность, визуально-информационная культура, медийная культура, информационно-коммуникативные процессы. 